Can employees perform well if they fear for their lives? Yes-if they have a passion for work

Inam Ul Haq

Dirk De Clercq

Muhammad Umer Azeem

Paper accepted for Personnel Review 


\title{
Can employees perform well if they fear for their lives? Yes-if they have a passion for work
}

\begin{abstract}
Purpose - With a basis in conservation of resources theory, this study investigates the mediating role of championing behaviour in the relationship between employees' fear of terror and their job performance, as well as the buffering role of their passion for work, as a personal resource, in this process.
\end{abstract}

Design/methodology/approach - The tests of the hypotheses rely on three-wave, time-lagged data collected from employees and their supervisors in Pakistan.

Findings - An important reason that concerns about terrorist attacks diminish performance is that employees refrain from championing their own entrepreneurial ideas. This mediating role of idea championing is less salient, however, to the extent that employees feel a strong passion for their work.

Practical implications-For human resource managers, this study pinpoints a key mechanisma reluctance to mobilize active support for entrepreneurial ideas - by which fears about terrorism attacks can spill over into the workplace and undermine employees' ability to meet their performance requirements. It also reveals how this mechanism can be better contained by the presence of adequate personal resources.

Originality/value - This study adds to burgeoning research on the interplay between terrorism and organizational life by specifying how and when employees' ruminations about terrorism threats might escalate into diminished performance outcomes at work.

Keywords - fear of terror; championing behaviour; passion for work; job performance; conservation of resources theory

Paper type-Research paper 


\section{Introduction}

The fear of terror is prominent in many countries, particularly those marked by political instability and extremism (Bader and Berg, 2013: Hussain and Azam, 2016; Mushtaq and Rehman, 2016; Toker et al., 2015). Such fear can manifest itself in different ways, such as frequent ruminations about future terrorist attacks, the sense that nothing can be done to avoid such attacks, the belief that terrorism will only get worse as time passes, or a feeling of a general lack of control in protecting oneself and loved ones from violence (Sinclair and LoCicero, 2006). An inability to avoid thinking about the threat of terrorism negatively interferes with people's quality of life and peace of mind in their daily functioning (Herzenstein et al., 2015; Somer et al., 2005; Toker et al., 2015), but fears of terror also might exert an effect in the workplace, by undermining employees' organizational functioning (Bader and Berg, 2014; Comfort, 2002; Howie, 2007; Liou and Lin, 2008; Toker et al., 2015). For example, fears of terror might reduce employees' work satisfaction (Kastenmuller et al., 2014) and work concentration (Mainiero and Gibson, 2003), spur their absenteeism (Mushtaq and Rehman, 2016) and job burnout (Toker et $a l ., 2015$ ), and ultimately undermine their ability to fulfil performance requirements (Bader and Berg, 2013; De Clercq et al., 2017).

To extend this research line, the current study addresses another reason that employees' fear of terror might lead to poor performance, namely, because it takes up energy that employees otherwise could devote to undertaking productive entrepreneurial behaviours. In particular, if employees suffer this resource constraint, it may diminish their propensity to champion their entrepreneurial ideas - those that deviate from the status quo and have the potential to add to organizational success (De Clercq et al., 2011; Kelley, 2011) — that otherwise might contribute to the organization's success (Scott and Bruce, 1994; Walter et al., 2011). Such discretionary, 
championing activities are critical to effective organizational functioning (Maimone and Sinclair, 2014; Oltra and Vivas-López, 2013; Scott and Bruce, 1994). As prior literature acknowledges, it is less the generation and more the active lobbying for and promotion of entrepreneurial ideas that enhance organizations' competitive advantages (De Clercq et al., 2011; Perry-Smith and Mannucci, 2017; Van de Ven, 1986).

Despite the usefulness of championing entrepreneurial ideas, such activities may be costly for the promoters, especially if other organizational members regard their actions as intrusive or threatening (Day, 1994; Walter et al., 2011). Further, mobilizing support for disruptive ideas might be perceived as self-serving, if the ideas appear to improve the work situations of the proponents but not the rest of the organization (Howell, 2005; Yuan and Woodman, 2010). In accordance with conservation of resources (COR) theory (Hobfoll, 1989, 2001), we propose that if employees already must devote resources to dealing with their fear of terror, they might exhibit poorer performance, because they seek to conserve their remaining resources and thus are reluctant to engage in energy-consuming championing behaviours (Howell and Boies, 2004; Perry-Smith and Mannucci, 2017). Notably, a person's propensity to avoid creative or innovative behaviours is a causal mechanism that links negative workplace conditions (e.g., work role stressors, Mishra and Shukla, 2012; surface acting, Liu et al., 2013) to diminished work outcomes. No prior empirical research has investigated this potential mediating effect in relation to the performance effects of a fear of terror though.

In turn, this study elucidates how organizations might contain negative behavioural responses to fears of terror. In particular, and consistent with COR theory, employees' passion for work (Klaukien et al., 2013), as an important personal resource, might reduce the likelihood that employees react to their fears with reduced championing behaviour. Passion for work 
reflects employees' desire to work hard and the associated satisfaction they derive from expending significant energy in work-related activities (Baum and Locke, 2004; De Clercq and Belausteguigoitia, 2017). In line with this logic, the personal resource of passion for work may reduce the likelihood that the resource drainage employees experience due to constant worries about terrorism enters the workplace, in the form of reduced idea championing efforts (Hobfoll, 2001). That is, when they exhibit a strong passion for work, the negative influence of employees' fear of terror on their championing behaviour should be buffered (Hobfoll and Shirom, 2000), which in turn should have positive consequences for their performance (Walter et al., 2011).

\section{Contributions}

Investigating these relationships produces several contributions to extant literature. First, this research reveals that a fear of terror can spill over and escalate into lower job performance, due to employees' reluctance to champion their entrepreneurial ideas (Hobfoll, 1989, 2001). This spillover effect is consistent with previous applications of COR theory to the study of terrorism threats, a theory that "places a strong emphasis on downward spirals through which resource loss in one domain (e.g., negative effects of terror on general well-being) may exacerbate resource depletion in other domains (e.g., work-related well-being)" (Toker et al., 2015: p. 274). The difficulty of avoiding thoughts about terrorism can thwart employees' ability to meet their performance targets, because they lack the stamina to undertake productive, energy-consuming activities (De Clercq et al., 2017; Howell, 2005; Markham, 1998). Prior research indicates that when employees fear for their personal safety or the safety of their loved ones, because they anticipate future terrorist attacks, they exhibit lower job performance due to elevated levels of job-related anxiety (De Clercq et al., 2017). The current study contributes to such research into the process by which perceived terrorism threats undermine positive work outcomes by 
pinpointing an unexplored behavioural mechanism, namely, by limiting the idea championing that otherwise might enhance organizational success (Howell and Shea, 2001; Walter et al., 2011). Formally, the diminished likelihood that employees actively work to mobilize support for their entrepreneurial ideas is a critical but largely ignored mechanism that might explain why terrorism threats lead to underperformance in workplaces.

Second, in response to calls for more studies that consider contingency approaches to the outcomes of perceived terrorism threats (De Clercq et al., 2017; Junaid and Haar, 2015; Toker et al., 2015), this study offers new insights into how the likelihood of poorer performance due to the presence of terrorism fears might be mitigated by employees' passion for work (Baum and Locke, 2004). Employees likely respond differently to their fear, depending on whether they possess pertinent personal resources that help them cope with it (Hobfoll and Shirom, 2000). In line with research that cites buffering roles of self-efficacy (Junaid and Haar, 2015), religiousness (De Clercq et al., 2017), and coworker support (Toker et al., 2015) for containing the negative outcomes of terrorism threats, this study reveals how employees' positive energy toward work mitigates the mediating effect by which reduced championing behaviour links a fear of terror to reduced job performance (Quinn et al., 2012). This approach accordingly provides human resource managers with detailed insights into how their organizations can protect themselves from the negative interference of terrorism threats with employees' work activities, namely, by recruiting and retaining employees who exhibit a strong passion for work. Moreover, our focus on the mitigating effect of passion for work on the negative outcomes of a fear of terror complements previous studies that investigate an invigorating or activating role of this fear on the relationship of job involvement with helping behaviour (De Clercq et al., 2019) or between government authoritarianism and the curtailment of civil liberties (Norris, 2017). 
Third, this study's empirical context of Pakistan represents an extension and response to calls for more studies of disruptive work behaviours in non-Western settings (e.g., Jam et al., 2017; Liu et al., 2018). Pakistan has been the victim of many terrorist attacks and associated safety concerns (Hussain and Azam, 2016; Ismail and Amjad, 2014; Mushtaq and Rehman, 2016), so it offers a relevant, pertinent setting in which to investigate the likelihood that fears of terrorism might spill over into the workplace and escalate into negative behavioural outcomes. Its unstable political climate means that terrorism attacks are realistic threats for many employees (Shahzad et al., 2016). The proposed conceptual framework thus should be informative for this country, as well as other nations that share similar political and securityrelated issues. The consideration of passion for work as a means to cope with harmful workrelated consequences of fears of terrorism has practical value as well (Gulyani and Bhatnagar, 2017). That is, by unpacking the relationship between a fear of terror and job performance, this study provides organizations that operate in politically unstable environments with important insights into why some employees may be better able than others to meet performance targets.

In summary, the conceptual framework in Figure 1, anchored in COR theory (Hobfoll, $1989,2001)$, proposes that the fear of terror thwarts job performance because the associated energy depletion steers employees away from actively promoting their entrepreneurial ideas. This championing behaviour thus mediates between a fear of terror and job performance. Passion for work serves as a buffer, such that the translation of persistent concerns about future terrorist attacks into reduced job performance, through reduced idea championing, becomes less likely when employees derive personal joy from their work.

[Insert Figure 1 about here]

\section{Theoretical background}


Employees can add to their organization's success through active championing of entrepreneurial ideas (Howell and Boies, 2004; Van de Ven, 1986; Walter et al., 2011). Ideas that are novel to the organization have the potential to improve the status quo (Amabile, 1988; Shalley and Gilson, 2004; Yuan and Woodman, 2010). Mobilizing support for their new ideas has positive consequences for both organizations and the employees themselves, in that their championing efforts can add to their understanding of the organization's decision-making processes (Van Laere and Aggestam, 2016), contribute to their development of inter-firm networks (Coakes and Smith, 2007), and enhance their job performance (Kissi et al., 2013). Yet the active promotion of entrepreneurial ideas also tends to be challenging for employees, especially if colleagues find their efforts intrusive (Day, 1994; De Clercq et al., 2011; Zhou and George, 2001). That is, when employees push their novel ideas, the targets of their efforts may exhibit resistance to the extent that they feel threatened by potential workplace changes (Walter et al., 2011; Yuan and Woodman, 2010).

This resistance might become especially problematic when employees also face other personal or work-related challenges. For example, employees are less likely to devote energy to generating or promoting entrepreneurial ideas if they suffer a lower ability to understand and assimilate external knowledge (Lin et al., 2014), feel unhappy about their organization's strategic direction (De Clercq et al., 2011), or are not committed to their employer (Wichmann et al., 2015). Further, while championing behaviours already can be diminished due to internal work-related causes, it also is useful to clarify why employees might avoid pushing their entrepreneurial ideas in response to other, external resource drains that leave them with limited residual energy to engage in such activities (Hobfoll and Shirom, 2000; Quinn et al., 2012), with negative consequences for their performance (Howell and Shea, 2001; Kissi et al., 2013). 
The central premise of this study is that concerns about terrorism attacks might function as just such an external inhibitor of championing behaviours (Sinclair and LoCicero, 2007). This condition generates significant stress in employees' daily lives and work lives (Bader and Berg, 2014; Howie, 2007). The behavioural consequences of terrorism have been described in sociology and disaster research, focusing on outcomes such as group cohesion and helping behaviours (Drabek and McEntire, 2003; Fisher, 2002; cf. Reade, 2009). In addition, terror management theory (TMT), with roots in psychology, suggests that when employees feel helpless to protect themselves against terrorism, their mortality salience gets activated, and they become strongly aware that their lives are finite and death is an unavoidable reality (Burke et al., 2010), which in turn might enhance their anxiety and lead them to redirect their focus to personal instead of professional well-being (Yum and Schneck-Hamlin, 2005). However, as De Clercq and colleagues (2017: p. 24) point out, "whereas TMT theory focuses on the effects of perceived threats of terrorism and mortality salience on the experience of anxiety in general (Burke et al., 2010; Greenberg et al., 1986), it devotes less attention to how such perceptions might influence people in an organizational setting." These authors instead suggest COR theory as a relevant managerial theory, which they apply to show that perceived threats of terrorism can compromise employees' job performance due to feelings of job-related anxiety, a process mitigated by their religiousness (De Clercq et al., 2017).

Similarly, we propose that employees' fear of terror may drain their personal energy resources to such an extent (Greenberg et al., 1986; Toker et al., 2015) that they cannot undertake energy-consuming championing activities or perform as well. The connection between perceived terrorism threats and employees' dedication to championing activities at work might appear somewhat remote, yet it aligns with previous research at the nexus of terrorism and 
management that postulates that such threats compromise employees' sense of "initiative [or] ability to actively initiate and control organization-relevant behaviour" (Kastenmüller et al., 2014: p. 424). Consistent with COR theory, employees' stressful, resource-draining expectations of terrorism may diminish their ability to meet the performance expectations set by their organization, due to their associated desire to protect and conserve their remaining resource bases and resultant decision not to dedicate significant efforts to idea championing (Abbas et al., 2014; Hobfoll, 2001). Similarly, and as previous applications of COR theory reveal, employees' inability to meet performance targets is shaped not only by resource-draining factors directly tied to their work settings but also by those that originate from outside, such as family incivility (Lim and Tai, 2014), efforts to balance family and work obligations (Witt and Carlson, 2006), or a negative interplay between personal and professional lives (Ballesteros-Leiva et al., 2017).

To elaborate on how employees' fear of terror might escalate into diminished productive work efforts, and thus poorer performance, as well as how this effect might be contained (De Clercq et al., 2017; Junaid and Haar, 2015), this study also relies on COR theory to predict that behavioural reactions to adverse, resource-draining situations vary with the personal resources available to employees (Abbas et al., 2014; Hobfoll and Shirom, 2001). In particular, if employees' passion for work (Baum and Locke, 2004) buffers against the drainage of energy resource reservoirs due to their continued ruminations about future terrorism, it may diminish the likelihood that this resource drainage leads to reduced championing efforts and poorer job performance. That is, employees' passion for work may provide positive, work-related energy that they can leverage in challenging situations (De Clercq and Belausteguigotia, 2017; Klaukien et al., 2013), such as when they believe that they cannot defend against future terrorist attacks (Toker et al., 2015). Formally, when equipped with a strong passion for work, the negative effect 
of employees' exposure to terrorism threats on their job performance, through reduced idea championing, should be attenuated.

\section{Hypotheses}

Mediating role of championing behaviour

Previous research indicates that the stress employees experience in one sphere (e.g., personal) can spill over and negatively influence attitudes and behaviours in another sphere (e.g., work; Lim and Tai, 2014; Nohe et al., 2014). Energy resource losses due to adverse conditions outside the workplace may undermine employees' ability to allocate significant time to discretionary, energy-consuming work activities (Hobfoll and Shirom, 2000; Quinn et al., 2012). Studies show, for example, that the belief that family obligations negatively interact with work duties represents a significant source of workplace stress that depletes employees' energy reservoirs, leaving them reluctant to engage in productive activities that otherwise could contribute to organizational effectiveness (Witt and Carlson, 2006; Zhang et al., 2012). Previous applications of COR theory to the specific case of terrorism similarly suggest that perceived threats of terrorism may generate enhanced workplace anxiety and burnout (De Clercq et al., 2017; Toker et al., 2005).

When employees frequently think about the threat of future terrorism, it may drain the energy resources from which they can draw to seek support actively for their entrepreneurial ideas (Hobfoll and Shirom, 2000; Walter et al., 2011). Such ideas are often disruptive, so employees likely anticipate significant scepticism in response to their efforts to sell their entrepreneurial ideas to other organizational members, who might feel threatened by potential changes to their current privileges (Howell, 2005; Markham, 1998; Yuan and Woodman, 2010). According to COR theory, the hardships that employees experience when they ruminate about 
terrorism attacks may deplete the positive energy resources that they otherwise could dedicate to engaging in such challenging championing activities (Hobfoll, 2001; Toker et al., 2015). Conversely, if employees rarely dwell on the threat of future terrorism, they have more discretionary energy at their disposal that they can allocate to mobilizing support for their entrepreneurial ideas (Quinn et al., 2012). That is, employees should be more likely to promote their ideas actively to the extent that they believe they are safe from terrorism.

Moreover, the possibility of terrorism attacks might create a sense that championing efforts are not worthwhile, because an act of terrorism could undermine the past and future success of their organization at any time (Comfort, 2002; Howie, 2007). This belief may spur a general sense of discouragement, such that they feel little motivation to go out of their way to champion entrepreneurial ideas (Hobfoll, 2001). That is, the broader political environment and its potentially negative impact on their organization's future could thwart employees' motivation to mobilize support for their entrepreneurial ideas, because such efforts appear to be in vain (Junaid and Haar, 2015; Toker et al., 2015). In contrast, if employees believe the organization's well-being is not threatened by external attacks, they should regard discretionary work activities as meaningful and valuable and feel encouraged to engage in sustained championing efforts that might enhance the organization's success (Howell and Boies, 2004; Walter et al., 2011).

In short, ruminations about terrorism attacks may compromise employees' ability and motivation to mobilize other members to endorse their entrepreneurial ideas. In light of the positive contributions that active promotions of entrepreneurial ideas tend to have for organizational effectiveness and growth (Howell, 2005; Schon, 1994), such that organizational decision makers appreciate such efforts (Kissi et al., 2013; Van Laere and Aggestam, 2016), employees' reluctance to mobilize support for their entrepreneurial ideas may constitute an 
important mechanism through which a fear of terror undermines their performance. That is, exposure to terrorism threats diminishes job performance because employees exhibit a lower propensity to go out of their way to promote entrepreneurial ideas that could increase organizational effectiveness.

Hypothesis 1: Employees' championing behaviour mediates the relationship between their fear of terror and job performance.

\section{Moderating role of passion for work}

According to COR theory, employees' negative behavioural reactions to adverse resource-draining circumstances vary with their possession of personal resources that influence their ability to cope with such circumstances (Abbas et al., 2014; Hobfoll, 2001). People marked by high levels of passion tend to be more resilient (Fisher et al., 2018; Singh et al., 2016) and experience positive energy during the execution of their work tasks (Baum and Locke, 2004), which in turn could enhance their ability to undertake energy-consuming championing efforts, even when they feel stressed by the threat of terrorism (Gulyani and Bhatnagar, 2017; Klaukien et al., 2013). That is, the positive feelings derived from passion for work expand the repertoire of cognitive tools available to employees who fear terrorism attacks (Vallerand et al., 2003), leaving more room for discretionary behaviours such as idea championing. In contrast, employees who lack a strong passion for work may not be able to protect themselves against the hardships that come with exposure to terrorism threats, because they have less ability to adapt to stressful situations (De Clercq and Belausteguigoitia, 2017), so they likely react to salient terrorism threats with a reluctance to engage in energy-consuming work activities (Hobfoll, 2001), such as disruptive championing behaviours.

Furthermore, employees equipped with a strong passion for work likely can build better work relationships with others (Ho and Pollack, 2014), so they might be in a better position to 
obtain advice about how to mitigate their concerns and retain sufficient energy for work activities (Toker et al., 2015). Similarly, employees with a strong passion for work tend to be more strongly involved with their job in the face of adverse conditions, which might increase their ability to cope with these situations (Cabrera and Cabrera, 2002) and diminish the chances that they avoid productive work activities (Klaukien et al., 2013). When exposed to terrorism threats, passionate employees thus should be better able to avoid negative interferences between their resource-draining fears about terrorism attacks and their propensity to push their entrepreneurial ideas (Hobfoll and Shirom, 2000).

Employees marked by high levels of passion for work also tend to feel attracted to difficult situations, because finding ways to thrive despite challenges can provide personal fulfilment (Baum and Locke, 2004; Vallerand et al., 2003). Thus, passion for work might not only enhance employees' ability to address the negative consequences of terrorism threats but also generate a sense of intrinsic motivation if they can contribute actively to their organization's success (Ryan and Deci, 2000). In this sense, it may attenuate the potency with which employees' fear of terror diminishes their championing behaviours, by enhancing the desirability of taking on the challenging task of mobilizing support for disruptive new ideas (Klaukien et al., 2013). Similarly, employees who are passionate tend to commit to pursuing challenging work goals, particularly if their attainment can help the employees deal with unfavourable situations (De Clercq et al., 2013). The extent to which employees exhibit a strong passion for work thus should encourage them to mobilize support for entrepreneurial ideas, including those that might help protect organizations from external threats such as terrorism (Gulyani and Bhatnagar, 2017; Howell and Shea, 2011). 
These arguments, in combination with the aforementioned mediating role of championing behaviour, suggest the presence of a moderated mediation effect (Preacher et al., 2007). That is, employees' passion for work offers a critical contingency of the indirect effect of a fear of terror on job performance, through championing behaviour. This moderated mediation implies that for passionate employees, the role of reduced championing behaviour as a causal mechanism that explains the negative relationship between fear of terror and job performance is weaker (Kissi et al., 2013; Walter et al., 2011). Conversely, the reluctance to engage in championing behaviour likely grows stronger when employees lack a strong passion for work, in which case their resource depletion due to terrorism threats is more likely to lead to poorer performance (Hobfoll, 2001). When employees cannot draw on a strong passion for work, their limited championing behaviour becomes a more important factor for explaining how their fear of terror contributes to thwarted job performance.

Hypothesis 2: The indirect relationship between employees' fear of terror and job performance through reduced championing behaviour is moderated by their passion for work, such that this indirect relationship is weaker among employees with greater passion for work.

\section{Research method}

Sample and data collection

The hypotheses tests rely on survey data collected from employees and supervisors in five Pakistani-based organizations located in the city of Lahore that operate in three industry sectors: banking, telecommunication, and education. Lahore has been the target of many terrorism attacks (including four large attacks since early 2017), and Pakistan ranks fifth in the list of countries most impacted by the terrorism since 2013, according to the Global Terrorism 
Index 2018. ${ }^{1}$ This empirical setting accordingly provides a suitable context to examine the impact of a fear of terror (De Clercq et al., 2017; Shahzad et al., 2016). Including the three distinct industries also ensures comprehensive coverage of different activities within the Pakistani economy, offering greater data heterogeneity and confidence in the external validity of the study findings. ${ }^{2}$ One of the authors leveraged existing business contacts to identify pertinent organizations in the different industry sectors and ensure the organizations' willingness to participate. The individual participants within organizations were identified through a random selection of employees from lists provided by the human resource offices of the respective organizations. Thus, whereas convenience sampling was used to identify organizations in a varied set of industries, the data collection within organizations was entirely random, and the participating employees were representative of their organizations. To account for possible industry-specific effects, the statistical analyses control for industry.

The data collection occurred in three waves, separated by three weeks each. These time gaps help avoid concerns about reverse causality—such that the promotion of entrepreneurial ideas and generation of solutions might minimize fears about the negative influences of terrorism, or improved performance might instil positive energy in employees that also spurs their championing efforts - but also are sufficiently short to reduce the risk that significant organizational events would occur during the research period. Moreover, the separation of the different survey rounds minimizes expectancy bias, that is, the chance that participants complete the surveys in a manner consistent with their prediction of the research hypotheses (e.g., that

\footnotetext{
${ }^{1}$ See http://visionofhumanity.org/app/uploads/2018/12/Global-Terrorism-Index-2018-1.pdf

${ }^{2}$ The surveys did not explicitly assess whether the organizations or their members had been victims of terrorism attacks in the past, but informal exchanges with organizational contact persons, before the data collection took place, generally indicated that concerns about terrorism are an inherent aspect of employees' daily lives, and organizational decision makers are aware of these concerns.
} 
their fear of terror would give them the "right" to avoid energy-consuming championing behaviours). One of the authors made personal visits to the organizations' sites to administer the surveys. After participants had filled out the surveys, they deposited them into sealed envelopes and returned them to this author. The participants were informed that the research findings would be useful for their organization's internal operations, but they did not receive any financial or other reward to take part. The surveys were administered in English, which is the language of formal business communication in Pakistan.

These data also may be subject to social desirability bias, so the research design applied well-established procedures to diminish such concerns, which also have been applied by previous studies in Pakistan (e.g., Abbas et al., 2014; Butt et al., 2005; Khan et al., 2015; Naseer et al., 2016). In particular, the invitation letters that accompanied the surveys promised the participants full confidentiality and emphasized that their participation was completely voluntary. The letters also noted that the individual responses would only be accessible to the research team and that only anonymous, aggregated data would be available to anyone else. Further, the study description explained that the surveys contained a personal code to facilitate data matching across the three rounds, but that this code would not undermine confidentiality. The participants also received explicit assurances that there were no right or wrong answers and were asked to respond to the survey items as honestly as possible, two tactics that further diminish social desirability bias (Spector, 2006). Finally, the invitation letters provided contact information for one author, in case the participants had any questions or wanted to provide feedback, and explained that the participants had the right to withdraw from the research at any time. Although social desirability bias cannot be completely ruled out, these standard procedures significantly reduce this concern. 
The first survey asked employees about their fear of terrorism and passion for work, and it also included a pertinent set of control variables (see the Measures subsection); the second survey assessed their engagement in championing behaviours. In the third survey, the employees' supervisors evaluated the employees' job performance. Of the 400 originally administered surveys, 293 were returned in the first round. In the second wave, 237 respondents completed the survey, and then 216 surveys were received from supervisors in the third wave. After removing surveys with incomplete data, 203 completed sets of surveys remained for the hypothesis tests.

\section{Measures}

The assessment of the study's constructs relied on previously validated measures, using five-point Likert scales ranging from 1 ("strongly disagree") to 5 (“strongly agree").

Fear of terror. Employees' fear of terror was assessed with a 13-item terrorism catastrophizing scale from Sinclair and LoCicero (2007). Sample items were "I often dwell on the threat of future terrorism," "I frequently think about the threat of future terrorism," and "I have difficulty keeping the threat of terrorism out of my mind" (Cronbach's alpha $=.86$ ).

Championing behaviour. To measure the extent to which employees actively promote their entrepreneurial ideas, this study relied on a three-item idea championing scale (Scott and Bruce, 1994): "I often mobilize support for entrepreneurial ideas," "I often acquire approval for entrepreneurial ideas," and "I often make important organizational members enthusiastic for entrepreneurial ideas" (Cronbach's alpha $=.73)$.

Job performance. Employees’ performance evaluations came from a seven-item supervisor-rated measure of job performance (Abbas et al., 2014; Williams and Anderson, 1991). For example, three measurement items were, "This employee performs the tasks that are 
expected of him/her," "This employee meets formal performance requirements of the job," and "This employee adequately completes assigned duties (Cronbach's alpha $=.71$ ).

Passion for work. A five-item scale, derived from Baum and Locke (2004), measured employees' passion for work. Example items were "I love to work," "I look forward to returning to work when I am away from work," and "I derive most of my life satisfaction from my work" $($ Cronbach's alpha $=.83)$.

Control variables. To assess whether the hypothesized spillover effect of employees' fear of terror to diminished championing behaviour and job performance is robust, the analyses contained various control variables. First, the analyses controlled for employees' gender $(1=$ female), because men might be more willing to speak up about novel ideas to other members than are women (Detert and Burris, 2007). Second, the models controlled for employees' education $(1=$ high school, 2 = college, non-university, $3=$ college, university, $4=$ masters, $5=$ $\mathrm{PhD})$ and monthly income $(1=$ below 25,000, $2=25,000-40,000,3=40,001-50,000,4=$ above 50,000 , measured in the local currency), because employees' social level may have an impact on the extent to which they are sensitive to terrorism threats and respond to them with reduced championing behaviour and job performance (Greenberg et al., 1986; Howie, 2007). Third, the analyses controlled for whether employees' job consisted mainly of fieldwork (e.g., selling mobile phones), which might leave them more exposed to terrorism threats. As further controls, the survey assessed employees' job levels $(1=$ managerial responsibilities $)$ and organizational tenure (in years), because employees with greater job responsibilities or who have worked for the organization for longer might feel more confident that they can convince colleagues of the value of their entrepreneurial ideas, even when they feel distressed by threats of terrorism (Tangirala and Ramanujam, 2008). Fourth, employees' championing behaviours and job 
performance might be influenced by their perceptions of how their organization treats them, so the analyses included a three-item measure of turnover intentions, such as "I will probably look for a new job in the near future" (Bozeman and Perrewé, 2001). Accordingly, this study investigates the salience of employees' fear of terror in predicting their championing behaviour and job performance, beyond the influence of their overall happiness with their work situation. Fifth, the controls for industry used two dummy variables, with education as the base category.

\section{Results}

Table 1 contains the correlations and descriptive statistics; Table 2 shows the hierarchical regression results. Models 1-3 predict championing behaviour, and Models 4-6 predict job performance. The variance inflation factors for the regression coefficients are each lower than 5.0, so multicollinearity is not a concern (Studenmund, 1992).

[Insert Tables 1 and 2 about here]

The results from the control models indicated that employees were more likely to undertake championing behaviour when they had worked for the organization for longer ( $\beta=$ $.032, p<.05$, Model 1) and had lower turnover intentions $(\beta=-.136, p<.05$, Model 1$)$, but they performed worse in their jobs when they engaged in fieldwork $(\beta=-.376, p<.05$, Model 4$)$ or wanted to leave the organization $(\beta=-.125, p<.01$, Model 4$)$.

To test whether the reluctance to engage in championing behaviour explicates how a fear of terror diminishes job performance (H1), it is necessary first to consider both relationships that constitute this mediation effect. The results showed that fear of terror diminished championing behaviour $(\beta=-.157, p<.05$, Model 2$)$, which diminished job performance $(\beta=.290, p<.001$, Model 6), as expected. As a formal check, the bootstrapping method suggested by Preacher and Hayes (2004), based on the Process macro developed by Hayes (2013), generates confidence 
intervals (CIs) for indirect effects and thus avoids statistical power problems that may arise with asymmetric or other non-normal sampling distributions of the effects (MacKinnon et al., 2004). The CI for the indirect effect of fear of terror on job performance through championing behaviour did not include 0 [-.128, -.009], in support of the presence of mediation.

The test of the moderated mediation effect by passion for work (H2) started with an assessment of whether this personal resource moderated the negative relationship between fear of terror and championing behaviour. The interaction term, fear of terror $\times$ passion for work, predicts championing behaviour in Model 3, and the positive and significant interaction term ( $\beta$ $=.242, p<.001)$ confirmed a buffering role of passion for work. Figure 2 depicts the nature of this effect by plotting the effect of fear of terror on championing behaviour at high and low levels of passion for work. A corresponding simple slope analysis (Aiken and West 1991) also indicated that the relationship between fear of terror and championing behaviour was negative and strongly significant at low levels of passion for work $(\beta=-.409, p<.001)$ but insignificant at high levels $(\beta=.075, n s)$.

\section{[Insert Figure 2 about here]}

To test formally for the presence of moderated mediation, as stipulated in $\mathrm{H} 2$, this study used Preacher et al.'s (2007) approach and Hayes's (2013) Process macro. Similar to the bootstrapping method to test for mediation, this approach generates CIs rather than point estimates, but for conditional indirect effects in this case (MacKinnon et al., 2004). The CIs also are estimated at different levels of the moderator (i.e., 10th, 25th, 50th, 75th, and 90th percentiles). In line with the conceptual framework, the estimated model included a moderating effect of passion for work on the relationship between fear of terror and championing behaviour but not the relationship between championing behaviour and job performance. A post hoc 
analysis indicated, as expected, that passion for work did not significantly moderate the relationship between championing behaviour and job performance. Using 10,000 random samples and replacement from the full sample, the results revealed that the bootstrap 95\% CI for the conditional indirect effect of fear of terror on job performance at the 10th, 25th, and 50th percentiles did not contain 0 ([-.294, -.058], [-.165, -.036], and [-.104, -.001], respectively), but the intervals contained 0 at the 75 th and 90 th percentiles of passion for work $([-.075, .043]$ and [$.064, .069]$, respectively). As a direct assessment of the presence of moderated mediation, the index of moderated mediation equalled .079, and its corresponding CI did not include 0 ([.016; .149]) (Hayes, 2015). Therefore, passion for work buffered the negative indirect effect of fear of terror on job performance, through championing behaviour, in support of $\mathrm{H} 2$ and the overall conceptual framework.

Although the conceptual focus of this study is on the concurrent interplay of employees' fear of terror and passion for work in explaining championing behaviour and subsequent job performance, a post hoc analysis also accounted for potential interdependencies between the first two constructs, as well as between the first construct and the different control variables. For example, the extent to which employees ruminate about terrorism threats might be influenced by their passion for work, gender, or position in society and the organization. Accordingly, a path model included the covariances among each of these variables, an approach that is consistent with prior research (De Clercq et al., 2009). The hypothesized effects matched the regression results in Table 2. That is, the direct relationships between fear of terror and championing behaviour and between championing behaviour and job performance, as well as the moderating effect of passion for work, were robust even after accounting for possible causal interdependencies. 


\section{Discussion}

This study contributes to existing research by examining the role of fear of terror in predicting employees' job performance, with a special focus on factors that inform this process. Despite growing attention to how beliefs about terrorism threats might negatively interfere with work efforts (De Clercq et al., 2017; Junaid and Haar, 2015; Toker et al., 2015), insufficient research provides behavioural explanations of why employees' performance might suffer due to their ruminations about terrorism, let alone how their personal resources might limit their negative behavioural responses. In accordance with the logic of COR theory (Hobfoll, 2001), this study explicates that (1) poorer work performance in the presence of terrorism threats can be explained by employees' reluctance to undertake productive championing behaviours, due to their lack of energy resources, and (2) their passion for work buffers this effect. The results provide empirical support for these theoretical arguments.

Ruminations about terrorism sensitize employees to their mortality, and employees bring the resulting stress to work (Burke et al., 2010), which depletes their energy for productive work behaviours, such as idea championing (Bader and Berg, 2014). Mobilizing entrepreneurial ideas is challenging, because it can generate scepticism among other organizational members, who fear that novel ideas might highlight their own failures and shortcomings (Walter et al., 2011). This challenge should be particularly prominent when employees also must cope with the hardships associated with persistent thoughts about terrorism. Consistent with COR theory, employees whose energy resource reservoirs are depleted, due to their fear of terror, are less likely to dedicate significant energy to mobilizing support for their entrepreneurial ideas (Boon and Kalshoven, 2014). Both ability- and motivation-based mechanisms underpin this connection. Employees who believe that terrorism poses a realistic threat may lack the energy to promote 
their entrepreneurial ideas, especially in the face of resistance (Quinn et al., 2012), and they also may believe that it is not worthwhile to allocate significant time to these organization-enhancing activities, because their efforts might be nullified if their organization is going to be subject to terrorism attacks anyway (Howie, 2007).

Notably, this study offers the critical insight that employees' reluctance to promote entrepreneurial ideas is a critical channel by which their fear of terror can lead to poorer performance. When they refrain from championing activities, which otherwise could add to organizational effectiveness, organizational decision makers perceive that employees fall short of performing their essential duties, including finding innovative solutions to organizational shortcomings (Howell and Shea, 2001). For example, the psychological hardships that stem from fears about future terrorist attacks may cause employees to focus mostly on their personal relationships (Kastenmüller et al., 2011; Toker et al., 2015), leaving less room to undertake performance-enhancing championing activities. Conversely, if employees believe that terrorist attacks are unlikely, they should have sufficient energy to promote new ideas to enhance organizational performance.

In addition, the mediating role of championing behaviour is moderated by employees' passion for work. Critical in this regard is the COR logic that the reluctance to undertake energyconsuming championing behaviour, in response to external terrorism threats, is muted when employees can rely on a critical personal resource that helps constrain further resource losses (Baum and Locke, 2004; Hobfoll, 2001). Employees who feel positively energized by their work can more easily avoid a scenario in which continuous thoughts about terrorist attacks undermine their productive work behaviours, because they can cope with these thoughts more easily (Klaukien et al., 2013). This adjustment then leaves them with more residual energy to dedicate 
to discretionary championing activities, even in the presence of terrorism threats (Quinn et al., 2012). Passionate employees also may derive personal joy from mobilizing support for their entrepreneurial ideas in the presence of terrorism, because their ability to do so represents an attractive challenge (Vallerand et al., 2003). Employees who lack such passion for work are both less able and less motivated to engage in energy-consuming idea championing when they fear terrorist attacks, so their negative behavioural responses, in the form of reduced championing behaviours, are more likely (Hobfoll, 2001).

The moderating effect of passion for work on the relationship between a fear of terror and championing behaviour is particularly insightful when considered in combination with the mediating role of championing behaviour. This moderated mediation dynamic reveals that the strength of the indirect effect of fear of terror on job performance through (reduced) championing behaviour depends on how passionate employees feel about work. That is, championing behaviour connects the resource-depleting condition to poorer job performance less powerfully when employees can draw on the personal resource of passion for work. Conversely, the resource drainage that results from terrorism threats translates into lower job performance with more strength, due to a reluctance to engage in energy-consuming championing behaviour, to the extent that employees feel less passionate about working hard (Hobfoll and Shirom, 2000).

Overall, this study offers a more complete understanding of the negative outcomes of people's concerns about terrorism. Previous research in the realm of management and organizations underscores that such concerns not only change people's attitudes and philosophy about life in general but also have important spillover effects on the ways that they function and perform at work (De Clercq et al., 2017; Howie, 2007; Kastenmuller et al., 2014; Toker et al, 2015). As an extension of such research, this study shows that a propensity to halt championing 
behaviours serves as a critical mechanism that connects employees' fear of terror to diminished job performance, and employees' passion for work mitigates this process. Although the scope of the tested conceptual model is somewhat narrow, the goal was to provide depth, rather than breadth, in pinpointing a hitherto unexplored mechanism by which fear of terror interferes with employees' ability to perform. Notably, the findings add to previous research on the direct positive influence of employees' passion for work on positive work outcomes, such as proactive work behaviours (Gulyani and Bhatnagar, 2017), the exploitation of new product opportunities (Klaukien et al., 2013), or new venture growth (Baum and Locke, 2004). In particular, the detrimental performance effect of reduced championing behaviour, in response to the fear of terrorism, can be contained by work-related passion that counters the resource depletion arising from such fear (Hobfoll, 2001), which represents a novel finding. To the extent that employees derive satisfaction from working hard, they can better manage the stress that comes with continuous ruminations about terrorism, so they retain sufficient energy and drive to promote their entrepreneurial ideas at work and achieve better performance.

\section{Limitations and future research}

This study has some shortcomings that offer opportunities for continued research. First, championing behaviour is a critical mechanism that underpins the negative performance consequences of employees' fears about future terrorist attacks (Bader and Berg, 2014; Toker $e t$ al., 2015), but other behavioural responses also could explain this link, such as employees' ability or willingness to engage in citizenship (Podsakoff et al., 2009) or voice (Morrison, 2011) behaviours. In a related vein, the ability and motivational arguments for the negative relationship between fear of terror and championing behaviour could be tested more explicitly in further research, to specify whether it is a lack of ability or motivation that is most prevalent in 
determining employees' behavioural responses to perceived terrorism threats. Yet another extension would be to explicitly assess the negative emotions or attitudes that might connect employees' fear of terror with their diminished championing behaviour, including anxiety (De Clercq et al., 2017), anger (Harmon-Jones and Sigelman, 2001), or a lack of harmonious work passion (Vallerand et al., 2003). ${ }^{3}$ Decomposing the fear of terror construct also might explicate the causes of anticipated terrorism events (e.g., politically oriented), who commits them (e.g., individuals or organized groups), and their severity (e.g., expected number of victims).

Second, this study centred on passion for work as one specific resource that buffers the translation of fear of terror into reduced championing behaviour and subsequent job performance. Additional studies could consider other contingency factors and personal resources, such as the number of terrorism events that employees have personally experienced in the past, their tolerance for fear (Izard, 1977), creative self-efficacy (Tierney and Farmer, 2002), emotional stability (Beehr et al., 2015), tenacity (Baum and Locke, 2004), or psychological capital (Sweetman et al., 2011). Supportive organizational context factors also might halt the process by which stress due to preoccupations about terrorism threats escalates into a reluctance to undertake productive work behaviours, such as an organizational climate that supports personal initiative (Scott and Bruce, 1994), transformational leadership (Dvir et al., 2002), or the availability of psychological counselling in crisis situations (Howie, 2007).

Third, the study sample consists of organizations that compete in three different sectors, so the analyses control for industry. The results offer empirical support for the hypotheses even with the inclusion of these industry control variables, which indicates that the results are robust

\footnotetext{
${ }^{3}$ This study measures passion for work with a scale that conceptualizes passion as a stable personality trait (Baum and Locke, 2004); other studies could use scales that conceptualize passion as a state that is changeable over time (Ho et al., 2011; Vallerand et al., 2003).
} 
to the presence of industry-specific factors that are not explicitly included in the models.

Nevertheless, a possibility of omitted variable bias remains, so continued studies might test other industry-level variables, such as the extent to which certain industries implement sector-specific training and support programs to help employees deal with their fear of terror (Liou and Lin, 2008) or develop measures to address concerns about social safety in general, as informed by sociology research (Tach and Edin, 2017). The degree to which employees' fear of terror diminishes their championing behaviour and subsequent job performance also might depend on an industry's competitive intensity or market turbulence (Covin and Slevin, 1989; Porter, 1996). Employees who work for organizations that are subject to excessive external rivalry might be more aware of the need for organizational innovation and creativity (Lahiri et al., 2008), such that the chances they respond to their fear of terror by reducing their championing behaviour could be subdued. Continued research could explicitly account for such industry factors.

Fourth, though the theoretical predictions are country neutral, it is possible that cultural factors influence the tested conceptual framework. Pakistan is marked by high levels of uncertainty avoidance, and employees might be particularly sensitive to stress-invoking circumstances such as terrorism threats that infuse uncertainty into their daily functioning (Hofstede, 2001; Mushtaq and Rehman, 2016). The buffering role of a personal resource such as passion for work in weakening the connection between fear of terror and job performance through championing behaviour thus may be particularly pertinent in countries with risk-averse cultural profiles. Cross-national studies could provide additional insights into the benefits of various personal characteristics for containing the hardships that result from ruminations about terrorism across different cultural environments. Another research path would be to compare the role of corresponding factors at the individual level, such as employees' personal risk orientation 
(Chow et al., 2012), to investigate how they moderate the relationship between fear of terror and employees' behavioural reactions to this fear.

\section{Practical implications}

The findings have important implications for human resource management practice. When employees worry extensively about the possibility of future terrorist attacks, they might turn away from productive entrepreneurial behaviours that would contribute to organizational effectiveness and their own performance evaluations, so organizations must seek to reduce such worries. However, employees might be hesitant to admit that they cannot keep the threat of terrorism out their minds, for fear of being ridiculed by colleagues as weak or scared (Howie, 2007; Toker et al., 2015). Human resource managers therefore should be proactive in identifying employees who likely suffer fears of terror and install organizational mechanisms to limit negative spillover effects. For example, support systems, including individual and group sessions, could encourage employees to express their preoccupations about their personal safety and the risk imposed by external threats of terrorism (Comfort, 2002; Liou and Lin, 2008). They also could communicate about specific measures that protect against damages if the company is a victim of terrorism attacks (Nissen et al., 2015).

Beyond this general recommendation, this study is particularly pertinent for defining ways in which pertinent personal resources can help employees cope with terrorism threats (Gulyani and Bhatnagar, 2017). To the extent that managers can recruit and retain employees who derive great satisfaction from their work, they can protect themselves better against the danger that their employee bases halt performance-enhancing entrepreneurial behaviours in response to external threats of terrorism. For example, managers could benefit from predicting and assessing the personal joy that employees take from making a difference to their 
organization's well-being through championing behaviours, even if they come to work with some stress due to negative external circumstances (Howell, 2005). They also might increase the likelihood that employees with a strong passion for work keep promoting new ideas for organizational improvement even in the presence of a fear of terror, by demonstrating that constructive ideas that add to the organization's success ultimately can help the organization reduce its own vulnerability to external threats of terrorism (Toker et al., 2015).

\section{Conclusion}

This study adds to previous research at the intersection of terrorism and human resource management by detailing the effect of employees' fear of terror on their performance evaluations at work, as well as the roles of their championing of entrepreneurial ideas and passion for work in this process. The tendency to avoid actively promoting entrepreneurial ideas is a critical reason that employees' repeated thoughts about terrorism negatively interfere with their ability to meet their performance targets at work. The strength of this explanatory mechanism is contingent, however, on how passionate employees feel about working hard. These findings in turn might inform future research endeavours pertaining to how human resource managers can prevent external security threats, including those that originate from terrorism, from entering the workplace and undermining the quality of employees' work. 


\section{References}

Abbas, M., Raja, U., Darr, W., and Bouckenooghe, D. (2014), "Combined effects of perceived politics and psychological capital on job satisfaction, turnover intentions, and performance”, Journal of Management, Vol. 40 No. 7, pp. 1813-1830.

Aiken , L.S., and West, S.G. (1991), Multiple Regression: Testing and Interpreting Interactions, Sage, Newbury Park, CA.

Amabile, T.M. (1988), "A model of creativity and innovation in organizations", Research in Organizational Behavior, Vol. 10 No. 1, pp. 123-167.

Bader, B., and Berg, N. (2014), "The influence of terrorism on expatriate performance: a conceptual approach", International Journal of Human Resource Management, Vol. 25 No. 4, pp. 539-557.

Ballesteros-Leiva, F., Poilpot-Rocaboy, G., and St-Onge, S. (2017), "The relationship between life-domain interactions and the well-being of internationally mobile employees", Personnel Review, Vol. 46 No. 2, pp. 237-254.

Baum, J.R., and Locke, E.A. (2004), "The relationship of entrepreneurial traits, skill, and motivation to subsequent venture growth", Journal of Applied Psychology, Vol. 89 No. 4, pp. 587-598.

Beehr, T.A., Ragsdale, J.M., and Kochert, J.F. (2015), "Effects of initial resources on the development of strains during a stressful training situation: some counterintuitive results", Journal of Organizational Behavior, Vol. 36 No. 4, pp. 467-490

Boon, C., and Kalshoven, K. (2014), "How high-commitment HRM relates to engagement and commitment: The moderating role of task proficiency", Human Resource Management, Vol. 53 No. 3, pp. 403-420.

Bozeman, D.P., and Perrewé, P.L., (2001), "The effect of item content overlap on organizational commitment questionnaire-turnover cognition relationships", Journal of Applied Psychology, Vol. 86 no. 1, pp. 161-173.

Burke, B.L., Martens, A., and Faucher, E.H. (2010), "Two decades of terror management theory: A meta-analysis of mortality salience research", Personality and Social Psychology Review, Vol. 14 No. 2, pp. 155-195.

Butt, A. N., Choi, J. N., and Jaeger, A. M. (2005), "The effects of self-emotion, counterpart emotion, and counterpart behavior on negotiator behavior: A comparison of individual level and dyad-level dynamics", Journal of Organizational Behavior, Vol. 26, No. 6, pp. 681-704.

Cabrera, A., and Cabrera, E.F. (2002), "Knowledge-sharing dilemmas", Organization Studies, Vol. 23 No. 5, pp. 687-710.

Chow, I.H.S., Ng, I., and Gong, Y.Y. (2012), "Risk-taking and relational perspective on turnover intentions", International Journal of Human Resource Management, Vol. 23 No. 4, pp. 779792.

Coakes, E., and Smith, P. (2007), "Developing communities of innovation by identifying innovation champions", The Learning Organization, Vol. 14 No. 1, pp. 74-85.

Comfort, L.K. (2002), "Rethinking security: Organizational fragility in extreme events", Public Administration Review, Vol. 62 No S1, pp. 98-107.

Covin, J.G., and Slevin, D.P. (1989), "Strategic Management of Small Firms in Hostile and Benign Environments”, Strategic Management Journal, Vol. 10 No. 1, pp. 75-87.

Day, D.L. (1994), "Raising radicals: different processes for championing innovative corporate ventures", Organization Science, Vol. 5 No. 2, pp. 148-172. 
De Clercq, D., and Belausteguigoitia, I. (2017), "Overcoming the dark side of task conflict: Buffering roles of transformational leadership, tenacity, and passion for work", European Management Journal, Vol. 35 No. 1, pp. 78-90.

De Clercq, D., Castañer, X., and Belausteguigoitia, I. (2011), "Entrepreneurial initiative selling within organizations: Toward a more comprehensive motivational framework", Journal of Management Studies, Vol. 48 No. 6, pp. 1269-1290.

De Clercq, D., Haq, I.U., and Azeem, M.U. (2017), "Perceived threats of terrorism and job performance: The roles of job-related anxiety and religiousness", Journal of Business Research, Vol. 78, No. 23-32.

De Clercq, D., Haq, I.U., and Azeem, M.U. (2019), "Threatened but involved: Key conditions for stimulating employee helping behaviour", Journal of Leadership and Organizational Studies, forthcoming.

De Clercq, D., Honig, B., and Martin, B. (2013), “The roles of learning orientation and passion for work in the formation of entrepreneurial intention”, International Small Business Journal, Vol. 31 No. 6, pp. 652-676.

De Clercq, D., Thongpapanl, N., and Dimov, D. (2009), "When good conflict gets better and bad conflict becomes worse: The role of social capital in the conflict-innovation relationship", Journal of the Academy of Marketing Science, Vol. 37 No. 3, pp. 283-297.

Detert, J.R., and Burris, E.R. (2007), "Leadership behavior and employee voice: Is the door really open?", Academy of Management Journal, Vol. 50 No. 4, pp. 869-884.Drabek, T.E. and McEntire, D.A. (2003), "Emergent phenomena and the sociology of disaster: lessons, trends, and opportunities from the research literature", Disaster Prevention and Management, Vol. 12 No. 2, pp. 97-112.

Dvir, T., Eden, D., Avolio, B. J., and Shamir, B. (2002), "Impact of transformational leadership on follower development and performance: A field experiment", Academy of Management Journal, Vol. 445, pp. 735-744.

Fischer, H.W. III (2002), "Terrorism and 11 September 2001: does the 'behavioral response to disaster' model fit?”, Disaster Prevention and Management, Vol. 11 No. 2, pp. 123-127.

Fisher, R., Merlot, E., and Johnson, L.W. (2018), "The obsessive and harmonious nature of entrepreneurial passion", International Journal of Entrepreneurial Behaviour and Research, Vol. 24 No. 1, pp. 22-40.

Greenberg, J., Pyszczynski, T., and Solomon, S. (1986), “The causes and consequences of a need for self-esteem: A terror management theory", In Baumeister R. F. (Ed.), Public Self and Private Self. Springer-Verlag, New York, pp. 189-212.

Gulyani, G., and Bhatnagar, J. (2017), "Mediator analysis of passion for work in Indian millennials", Career Development International, Vol. 22 No. 1, pp. 50-69.

Harmon-Jones, E., and Sigelman, J. (2001), "State anger and prefrontal brain activity: evidence that insult-related relative left-prefrontal activation is associated with experienced anger and aggression”, Journal of Personality and Social Psychology, Vol. 80 No. 5, pp. 797-803.

Hayes, A.F. (2013). Introduction to mediation, moderation, and conditional process analysis: A regression-based approach. New York: Guilford Press.

Hayes, A.F. (2015), “An index and test of linear moderated mediation”, Multivariate Behavioral Research, Vol. 50 No. 1, pp. 1-22.

Herzenstein, M., Horsky, S., and Posavac, S.S. (2015), "Living with terrorism or withdrawing in terror: Perceived control and consumer avoidance", Journal of Consumer Behaviour, Vol. 14, No. 4, pp. 228-236. 
Ho, V.T., and Pollack, J.M. (2014), "Passion isn't always a good thing: Examining entrepreneurs' network centrality and financial performance with a dualistic model of passion", Journal of Management Studies, Vol. 51 No. 3, pp. 433-459.

Ho, V., Wong, S., and Lee, C. (2011), “A tale of passion: Linking job passion and cognitive engagement to employee work performance", Journal of Management Studies, Vol. 48 No. 1 , pp. $26-41$.

Hobfoll, S.E. (1989), "Conservation of resources. A new attempt at conceptualizing stress. American Psychologist, Vol. 44 No. 3, pp. 513-524.

Hobfoll, S.E. (2001), "The influence of culture, community, and the nested-self in the stress process: Advancing conservation of resource theory", Applied Psychology: An International Review, Vol. 50 No.3 , pp. 337-369.

Hobfoll, S.E., and Shirom, A. (2000), "Conservation of resources theory: Applications to stress and management in the workplace", In R.T. Golembiewski (Ed.), Handbook of Organization Behavior (2d ed.). Dekker, New York, pp. 57-81.

Hofstede, G. (2001). Culture's Consequences: Comparing Values, Behaviors, Institutions and Organizations Across Nations ( $2 \mathrm{~d}$ ed.). Sage, Thousand Oaks, CA.

Howell, J.M. (2005), "The right stuff: identifying and developing effective champions of innovation", Academy of Management Executive, Vol. 19 No. 2, pp. 108-119.

Howell, J.M., and Boies, K. (2004), "Champions of technological innovation: the influence of contextual knowledge, role orientation, idea generation and idea promotion on champion emergence", Leadership Quarterly, Vol. 15 No. 1, pp. 123-143.

Howell, J.M., and Shea, C.M. (2001), "Individual differences, environmental scanning, innovation framing and champion behavior: Key predictors of project performance", Journal of Product Innovation Management, Vol. 18 No. 1, pp. 15-27.

Howie, L. (2007), "The terrorism threat and managing workplaces", Disaster Prevention and Management, Vol. 16 No. 1, pp. 70-78.

Hussain, S., and Azam, R. (2016), “An integrated model of stress, personality, social support and job outcomes: A study of the financial sector of Pakistan", Journal of Managerial Sciences, Vol. 10, pp. 55-72.

Ismail, A., and Amjad, S. (2014), "Determinants of terrorism in Pakistan: An empirical investigation", Economic Modelling, Vol. 37 No. C, pp. 320-331.

Izard, C.E. (1977), "Fear and the forms of anxiety", In: Human Emotions. Emotions, Personality, and Psychotherapy. Springer, Boston, MA

Jam, F., Donia, M.B.L., Raja, U., and Ling, C.H. (2017), “A time-lagged study on the moderating role of overall satisfaction in perceived politics: Job outcomes relationships", Journal of Management and Organization, Vol. 23 No. 3, pp. 321-336.

Junaid, F., and Haar, J. (2015), "Employees living under terrorism: Does positive organisational behaviour provide a lens for help (and hope)?", New Zealand Journal of Human Resources Management, Vol. 15 No. 2, 174-190.

Kastenmüller, A., Aydin, N., Frey, D., Traut-Mattausch, E., Peus, C., and Fischer, P. (2014), "Terrorist threat and employees' perceived ability to cope with organizational change", Journal of Applied Social Psychology, Vol. 44 No. 6, pp. 423-432.

Kastenmüller, A., Greitemeyer, T., Aydin, N, Tattersall, A.J., Peus, C., et al. (2011), "Terrorism threat and networking: Evidence that terrorism salience decreases occupational networking", Journal of Organizational Behavior, Vol. 32 No. 7, pp. 961-977. 
Kelley, D. (2011), "Sustainable corporate entrepreneurship: Evolving and connecting with the organization", Business Horizons, Vol. 54 No. 1, pp. 73-83.

Khan, K., Abbas, M., Gul, A., and Raja, U. (2015), "Organizational justice and job outcomes: Moderating role of Islamic work ethic", Journal of Business Ethics, Vol. 126 No. 2, pp. 236246.

Kissi, J., Dainty, A., and Tuuli, M. (2013), "Examining the role of transformational leadership of portfolio managers in project performance", International Journal of Project Management, Vol. 31 No. 4, pp. 485-497.

Klaukien, A., Shepherd, D.A., and Patzelt, H. (2013), "Passion for work, nonwork-related excitement, and innovation managers' decision to exploit new product opportunities", Journal of Product Innovation Management, Vol. 30 No. 4, pp. 574-588.

Lahiri, S., Pérez-Nordtvedt, L., and Renn, R.W. (2008), "Will the new competitive landscape cause your firm's decline? It depends on your mindset”, Business Horizons, Vol. 51, No. 4, pp. 311-320.

Lim, S., and Tai, K. (2014), "Family incivility and job performance: A moderated mediation model of psychological distress and core self-evaluation", Journal of Applied Psychology, Vol. 99, No. 2, pp. 351-359.

Lin, T.-C., Ku, Y.-C., and Huang, Y.-S. (2014), "Exploring top managers' innovative IT (IIT) championing behavior: Integrating the personal and technical contexts", Information and Management, Vol. 51 No. 1, pp. 1-12.

Liou, D.-Y., and Lin, C.-H. (2008), "Human resources planning on terrorism and crises in the Asia Pacific region: Cross-national challenge, reconsideration, and proposition from western experiences", Human Resource Management, Vol. 47 No. 1, pp. 49-72.

Liu, C., Liu, X., and Geng, Z. (2013), "Emotional labor strategies and service performance: The mediating role of employee creativity", Journal of Applied Business Research, Vol. 29 No. 5 , pp. $1583-1596$.

Liu, X.-Y., Kwa, H.K., and Zhang, X. (2018), "Introverts maintain creativity: A resource depletion model of negative workplace gossip", Asia Pacific Journal of Management, doi:10.1007/s10490-018-9595-7

MacKinnon, D.P., Lockwood, C.M., and Williams, J. (2004), "Confidence limits for the indirect effect: Distribution of the product and resampling methods", Multivariate Behavioral Research, Vol. 39 No. 1, pp. 99-128.

Maimone, F., and Sinclair, M. (2014), "Dancing in the dark: Creativity, knowledge creation and (emergent) organizational change", Journal of Organizational Change Management, Vol. 27, No. 2, pp. 344-361.

Mainiero, L. and Gibson, D. (2003), "Managing employee trauma: dealing with the emotional fall-out from 9/11”, Academy of Management Executive, Vol. 17 No. 3, pp. 130-44.

Markham, S.K. (1998), "A longitudinal study of how champions influence others to support their projects", Journal of Product Innovation Management, Vol. 15, pp. 490-504.

Mishra, R., and Shukla, A. (2012), "Impact of creativity on role stressors, job satisfaction and organisational commitment", Journal of Organisation and Human Behaviour, Vol. 1 No. 3 , pp. $18-26$

Morrison, E.W. (2011), "Employee voice behavior: Integration and directions for future research", Academy of Management Annals, Vol. 5 No. 1, pp. 373-412.

Mushtaq, K., and Rehman, R.R. (2016), "Examining absenteeism and deviant work behavior as the outcomes of PTSD caused by exposure to terrorism on medical professionals in 
Pakistan”, NUML International Journal of Business and Management, Vol. 11 No. 1, pp. 2348.

Naseer, S., Raja, U., Syed, F., Donia, M., and Darr, W. (2016), "Perils of being in-group of a bad leader: Exploring the combined effects of despotic leadership, leader member exchange, and perceived organizational politics on behaviors", Leadership Quarterly, Vol. 27 No. 1, pp. 1433.

Nissen, A., Birkeland Nielsen, M., Solberg, Ø., Bang Hansen, M., and Heir, T. (2015), "Perception of threat and safety at work among employees in the Norwegian ministries after the 2011 Oslo bombing", Anxiety, Stress, and Coping, Vol. 28 No. 6, pp. 650-662.

Nohe, C., Michel, A., and Sonntag, K. (2014), "Family-work conflict and job performance: A diary study of boundary conditions and mechanisms", Journal of Organizational Behavior, Vol. 35 No. 3, pp. 339-357.

Norris, G. (2017). Authoritarianism and privacy: The moderating role of terrorist threat. Surveillance \& Society, Vol. 15, No. 3/4, pp. $573-581$.

Oltra, V., and Vivas-López, S. (2013), "Boosting organizational learning through team-based talent management: What is the evidence from large Spanish firms?", International Journal of Human Resource Management, Vol. 24 No. 9, pp. 1853-1871.

Perry-Smith, J.E., and Mannucci, P.V. (2017), "From creativity to innovation: The social network drivers of the four phases of the idea journey", Academy of Management Review, Vol. 42 No. 1, pp. 53-79.

Podsakoff, N.P., Whiting, S.W., Podsakoff, P.M., and Blume, B.D. (2009), "Individual-and organizational-level consequences of organizational citizenship behaviors: A meta-analysis", Journal of Applied Psychology, Vol. 94 No. 1, pp. 122-141.

Porter, M.E. (1996). What is strategy? Harvard Business Review, Vol. 74 No. 6, pp. 61-81.

Preacher, K.J., and Hayes, A.F. (2004), "SPSS and SAS procedures for estimating indirect effects in simple mediation models", Behavior Research Methods, Instruments, and Computers, Vol. 36 No. 4, pp. 717-731.

Preacher, K. J., Rucker, D. D., and Hayes, A. F. (2007), “Assessing moderated mediation hypotheses: Theory, methods, and prescriptions", Multivariate Behavioral Research, Vol. 42, pp. 185-227.

Quinn, R.W., Spreitzer, G.M., and Lam, C.F. (2012), "Building a sustainable model of human energy in organizations: Exploring the critical role of resources", Academy of Management Annals, Vol. 6 No. 1, pp. 337-396.

Reade, C. (2009), "Human resource management implications of terrorist threats to firms in the supply chain", International Journal of Physical Distribution \& Logistics Management", Vol. 39 No. 6, pp. 469-485.

Ryan, R.M., and Deci, E.L. (2000), "Self-determination theory and the facilitation of intrinsic motivation, social development, and well-being", American Psychologist, Vol. 55 No. 1, pp. $68-78$.

Schon, D.A. (1963), "Champions for radical new inventions", Harvard Business Review, Vol. 41, No. 77-86.

Scott, S.G., and Bruce, R.A. (1994), "Determinants of innovative behavior: A path model of individual innovation in the workplace", Academy of Management Journal, Vol. 37 No. 3 , pp. 580-607. 
Shahzad, S.J.H., Zakaria, M., Rehman, M.U., Ahmed, T., and Fida, B.A. (2016), "Relationship between FDI, terrorism and economic growth in Pakistan: Pre and post 9/11 analysis", Social Indicators Research, Vol. 127 No. 1, pp. 179-194.

Shalley, C.E., and Gilson, L.L. (2004), "What leaders need to know: A review of social and contextual factors that can foster or hinder creativity", The Leadership Quarterly, Vol. 15 No. 1, pp. 33-53.

Sinclair, S.J., and LoCicero, A. (2006), "Development and psychometric testing of the perceptions of terrorism questionnaire short-form (PTQ-SF)", New School Psychology Bulletin, Vol. 4, pp. 7-37.

Singh, P., Burke, R.J., and Boekhorst, J. (2016), "Recovery after work experiences, employee well-being and intent to quit", Personnel Review, Vol. 45 No. 2, pp. 232-254.

Somer, E., Tamir, E., Maguen, S., and Litz, B.T. (2005), "Brief cognitive behavioral phonebased intervention targeting anxiety about the threat of an attack: A pilot study", Behaviour Research and Therapy, Vol. 43 No. 5, pp. 669-679.

Spector, P.E. (2006), "Method variance in organizational research: Truth or urban legend?", Organizational Research Methods, Vol. 9 No. 2, pp. 221-232.

Studenmund, A.H. (1992), Using Econometrics: A Practical Guide. Harper Collins, New York.

Sweetman, D., Luthans, F., Avey, J. B., and Luthans, B. C. (2011), "Relationship between positive psychological capital and creative performance", Canadian Journal of Administrative Sciences, Vol. 28 No. 1, pp. 4-13.

Tach, L., and Edin, K. (2017), "The social safety net after welfare reform: Recent developments and consequences for household dynamics", Annual Review of Sociology, Vol. 43, No.1 pp. 541-561.

Tangirala, S., and Ramanujam, R. (2008), "Exploring nonlinearity in employee voice: The effects of personal control and organizational identification", Academy of Management Journal, Vol. 51 No. 6, pp. 1189-1203.

Tierney, P., and Farmer, S. M. (2002), "Creative self-efficacy: Its potential antecedents and relationship to creative performance”, Academy of Management Journal, Vol. 45 No. 6, pp. 1137-1148.

Toker, S., Laurence, G.A., and Fried, Y. (2015), "Fear of terror and increased job burnout over time: Examining the mediating role of insomnia and the moderating role of work support", Journal of Organizational Behavior, Vol. 36 No. 2, pp. 272-291.

Vallerand, R.J., Blanchard, C., Mageau, G.A., Koestner, R., Ratelle, C., Leonard, M., Gagne, M., and Marsolais, J. (2003), "Les passions de l'âme: On obsessive and harmonious passion", Journal of Personality and Social Psychology, Vol. 85 No. 4, pp. 756-767.

Van de Ven, A. H. (1986), "Central problems in the management of innovation", Management Science, Vol. 32 No. 5, pp. 590-607.

Van Laere, J., and Aggestam, L. (2016), "Understanding champion behaviour in a health-care information system development project - how multiple champions and champion behaviours build a coherent whole", European Journal of Information Systems, Vol. 25 No. 1, pp. 47-63.

Walter, A., Parboteeah, K.P., Riesenhuber, F., and Hoegl, M. (2011), “Championship behaviors and innovations success: An empirical investigation of university spin-offs", Journal of Product Innovation Management, Vol. 28 No. 4, pp. 586-598. 
Wichmann, B.K., Carter, Craig R., and Kaufmann, L. (2015), "How to become central in an informal social network: An investigation of the antecedents to network centrality in an environmental SCM initiative”, Journal of Business Logistics, Vol. 36 No. 1, pp. 102-119.

Williams, L.J., and Anderson, S.E. (1991), "Job satisfaction and organizational commitment as predictors of organizational citizenship and in-role behavior", Journal of Management, Vol. 17 No. 3, pp. 601-617.

Witt, L.A., and Carlson, D.S. (2006), "The work-family interface and job performance: Moderating effects of conscientiousness and perceived organizational support", Journal of Occupational Health Psychology, Vol. 11 No. 4, pp. 343-357.

Yuan, F., and Woodman, R. (2010), "Innovative behavior in the workplace: The role of performance and image outcome expectations", Academy of Management Journal, Vol. 53, No. 2, pp. 323-342.

Yum, Y.-O., and Schneck-Hamlin, W. (2005), "Reactions to 9/11 as a function of terror management and perspective taking”, Journal of Social Psychology, Vol. 145 No. 3, pp. $265-286$.

Zhang, M., Griffeth, R.W., and Fried, D.D. (2012), "Work-family conflict and individual consequences", Journal of Managerial Psychology, Vol. 27 No. 7, pp. 696-713.

Zhou, J., and George, J.M. (2001), "When job dissatisfaction leads to creativity: Encouraging the expression of voice", Academy of Management Journal, Vol. 44 No. 4, pp. 682-696. 
Figure 1: Conceptual model

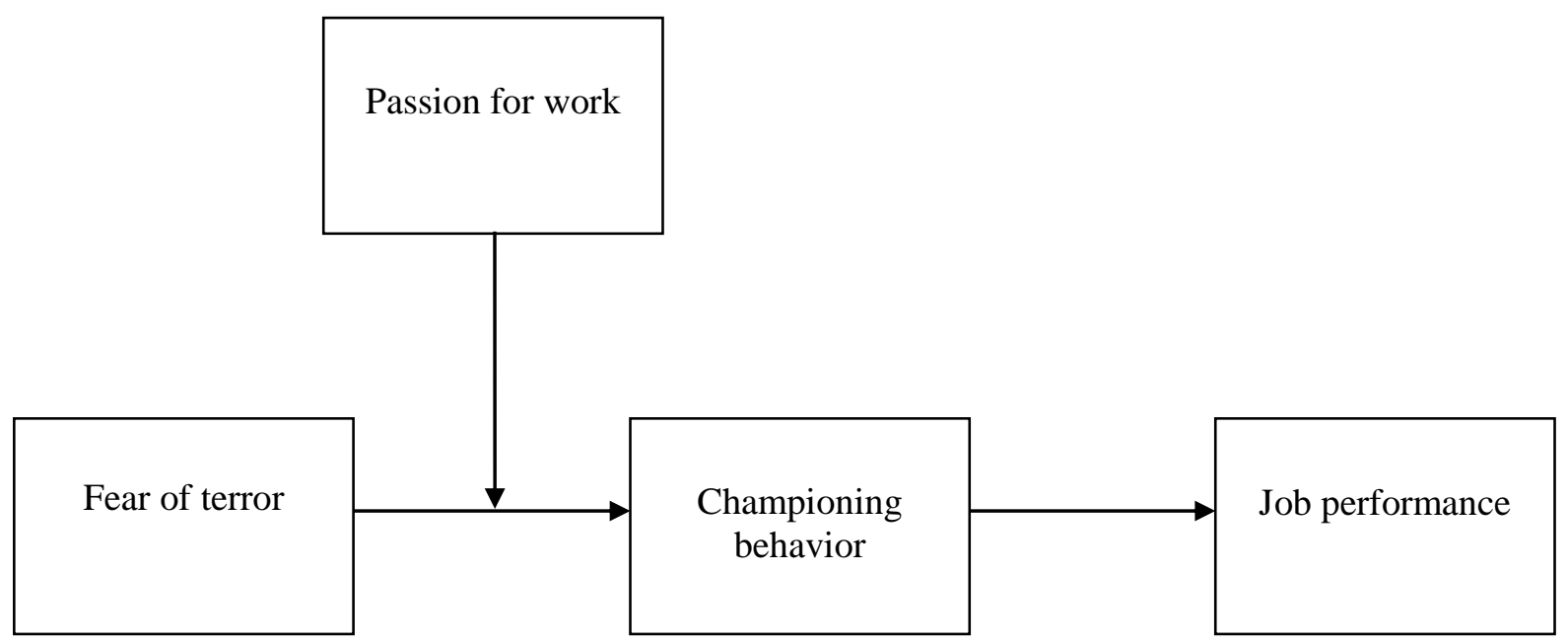


Figure 2: Moderating effect of passion for work on the relationship between fear of terror and championing behaviour

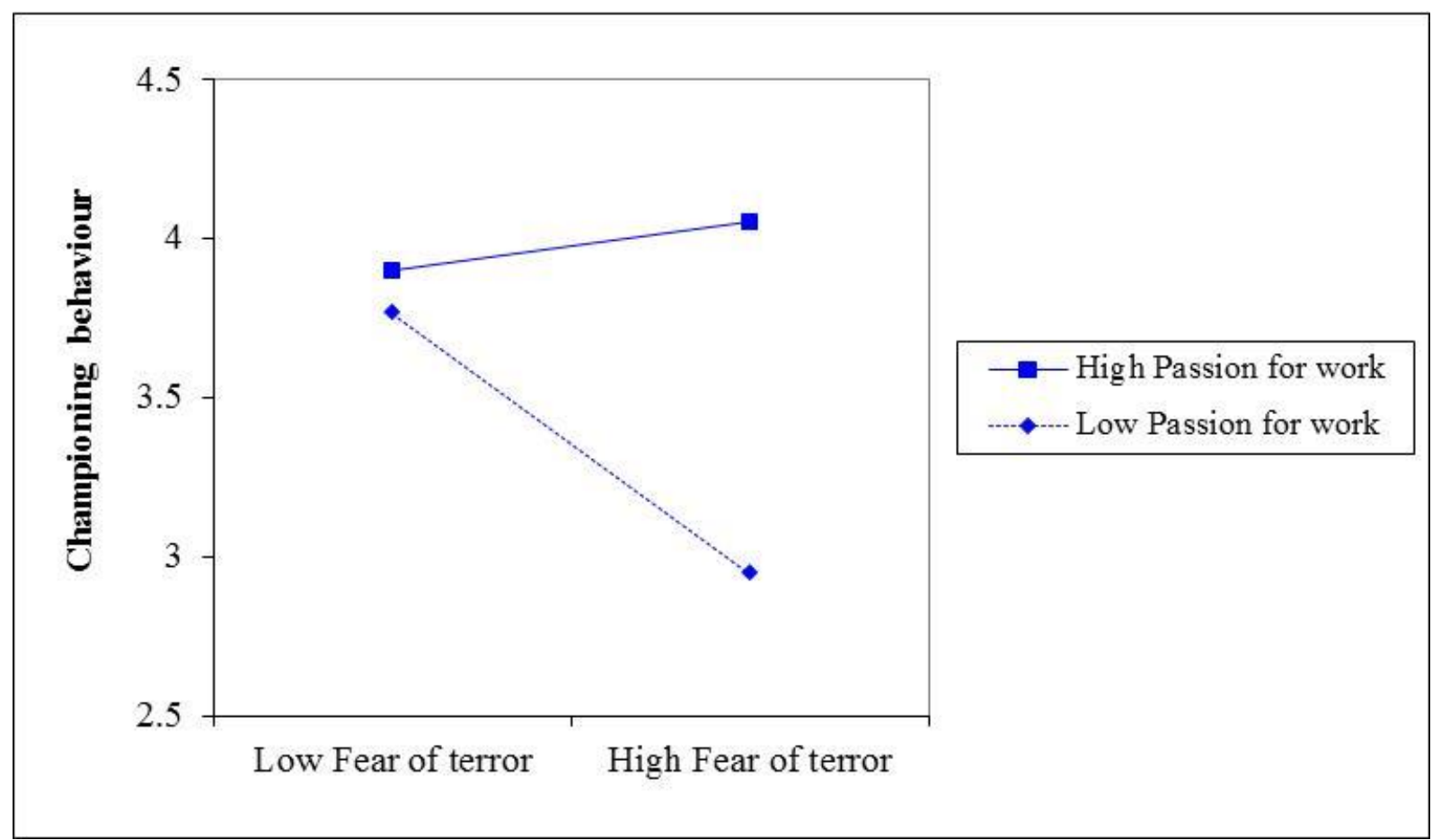


Table 1: Correlation table and descriptive statistics

\begin{tabular}{|c|c|c|c|c|c|c|c|c|c|c|c|c|c|c|}
\hline & 1 & 2 & 3 & 4 & 5 & 6 & 7 & 8 & 9 & 10 & 11 & 12 & 13 & 14 \\
\hline \multicolumn{15}{|l|}{ 1. Fear of terror } \\
\hline 2. Championing & $-.171 *$ & & & & & & & & & & & & & \\
\hline 3. Job performance & $-.400 * *$ & $.471 * *$ & & & & & & & & & & & & \\
\hline 4. Passion for work & .036 & $.381 * *$ & $.282 * *$ & & & & & & & & & & & \\
\hline 5. Gender $(1=$ female $)$ & .086 & -.106 & -.083 & -.062 & & & & & & & & & & \\
\hline 6. Education & .107 & .001 & .005 & $.237 * *$ & $.154 *$ & & & & & & & & & \\
\hline 7. Income & -.130 & $.159 *$ & $.236 * *$ & $.325 * *$ & $-.191 * *$ & $.310 * *$ & & & & & & & & \\
\hline 8. Fieldwork & .051 & -.021 & $-.146^{*}$ & .053 & -.070 & .027 & -.096 & & & & & & & \\
\hline 9. Job level & -.063 & .063 & .099 & $.155^{*}$ & -.045 & .096 & $.195^{* *}$ & -.087 & & & & & & \\
\hline 10. Organization tenure & -.002 & $.269 * *$ & $.202 * *$ & $.366^{* *}$ & -.088 & $.309 * *$ & $.576 * *$ & -.007 & $.155^{*}$ & & & & & \\
\hline 11. Turnover intention & $.372 * *$ & $-.228 * *$ & $-.230 * *$ & $-.156^{*}$ & .041 & $.161 *$ & -.119 & -.101 & .059 & $-.198 * *$ & & & & \\
\hline 12. Banking industry & .016 & -.112 & -.134 & $-.298 * *$ & $-.171 *$ & $-.407 * *$ & $-.309 * *$ & .105 & -.077 & $-.398 * *$ & .017 & & & \\
\hline 13. Telecom industry & .056 & .062 & -.027 & .029 & $.189 * *$ & .058 & .040 & -.104 & $.149 *$ & .097 & .077 & $-.471 * *$ & & \\
\hline 14. Education industry & -.069 & .056 & $.161 *$ & $.275 * *$ & -.001 & $.359 * *$ & $.276 * *$ & -.011 & -.060 & $.313 * *$ & -.089 & $-.580 * *$ & $-.446 * *$ & \\
\hline Mean & 2.775 & 3.672 & 3.808 & 3.551 & .473 & 3.833 & 2.562 & .059 & .108 & 5.742 & 2.818 & .379 & .266 & .355 \\
\hline SD & .731 & .731 & .611 & .868 & .500 & .778 & 1.029 & .236 & .312 & 5.147 & .996 & .486 & .443 & .480 \\
\hline Minimum & 1.231 & 1.000 & 1.714 & 1.000 & .000 & 1.000 & 1.000 & .000 & .000 & .500 & 1.000 & .000 & .000 & .000 \\
\hline Maximum & 4.692 & 5.000 & 5.000 & 5.000 & 1.000 & 5.000 & 4.000 & 1.000 & 1.000 & 28.000 & 5.000 & 1.000 & 1.000 & 1.000 \\
\hline
\end{tabular}

Notes: $\mathrm{N}=203$.

$* p<.05 ; * * p<.01$. 
Table 2. Regression results

\begin{tabular}{|c|c|c|c|c|c|c|}
\hline & \multicolumn{3}{|c|}{ Championing behaviour } & \multicolumn{3}{|c|}{ Job performance } \\
\hline & Model 1 & Model 2 & Model 3 & Model 4 & Model 5 & Model 6 \\
\hline Gender (1 = female $)$ & -.135 & -.098 & -.077 & -.058 & -.020 & .009 \\
\hline Education & -.030 & -.050 & -.057 & -.047 & -.045 & -.031 \\
\hline Income & -.013 & -.059 & -.056 & .078 & .026 & .043 \\
\hline Fieldwork & -.107 & -.153 & -.157 & $-.376^{*}$ & $-.357 *$ & -.313 \\
\hline Job level & .066 & -.057 & -.062 & .143 & .027 & .044 \\
\hline Organizational tenure & $.032 *$ & $.028 *$ & $.028 *$ & .006 & .009 & .001 \\
\hline Turnover intention & $-.136^{*}$ & -.062 & -.081 & $-.125 * *$ & -.020 & -.002 \\
\hline Banking industry ${ }^{a}$ & -.032 & .104 & .066 & -.161 & -.051 & -.081 \\
\hline Telecom industry & .094 & .161 & .153 & -.131 & -.068 & -.115 \\
\hline Fear of terror & & $-.157 *$ & $-.167 *$ & & $-.311 * * *$ & $-.266 * * *$ \\
\hline Passion for work & & $.303 * * *$ & $.310 * * *$ & & $.179 * * *$ & $.092^{+}$ \\
\hline Fear of terror $\times$ passion for work & & & $.242 * * *$ & & & \\
\hline Championing behaviour & & & & & & $.290 * * *$ \\
\hline $\mathrm{R}^{2}$ & .118 & .228 & .269 & .139 & .284 & .377 \\
\hline$\Delta \mathrm{R}^{2}$ & & $.110 * * *$ & $.041 * * *$ & & $.145 * * *$ & $.093 * * *$ \\
\hline
\end{tabular}

Notes: $\mathrm{n}=203$ (unstandardized regression coefficients).

${ }^{+} p<.10 ; * p<.05 ; * * p<.01 ; * * * p<.001$ (two-tailed tests).

${ }^{\text {a }}$ Education industry is the base category 